\title{
PENAEOID SHRIMPS (BENTHESICYMIDAE, ARISTEIDAE, SOLENOCERIDAE, SICYONHDAE) COLLECTED IN INDONESIA DURING THE CORINDON II AND IV EXPEDITIONS
}

\author{
by \\ ALAIN CROSNIER ${ }^{1}$ ) \\ INTRODUCTION
}

During the CORINDON II and IV expeditions, the former in the Makassar Strait and the latter in Piru Bay and Ambon Bay, Molluccas, 47 species of penaeoid shrimps were collected. They include 2 species belonging to the Benthesicymidae, 5 to the Aristeidae, 19 to the Solenoceridae, 2 to the Sicyoniidae and 19 to the Penaeidae.

The twenty eight species of the first four families are considered in this study; the Penaeidae will be presented in a separate publication.

Most of the species treated in this work occur in deep water, with only a few samples taken in shallow water. Two species Cryptopenaeus clevai and Solenocera moosai are new; eight others have not been recorded previously in the waters of Indonesia. Several specimens of Solencera innectens (Wood Mason, 1891) have been collected; this species has not been reported since its description and additional figures, particularly of genitalia, are included in this paper. One species of the genus Pseudaristeits and one of the genus Solenocera both probably new, are recorded but not named as only a single specimen of each was collected.

In addition to the description of Solenocera moosai, the original drawings of two closely related, but little known species, S. faxoni De Man, 1907 and S. spinajugo Hall, 1961, are published.

The bibliography is restricted to literature on Indonesian material. For each species, one or two references, each with comprehensive bibliographies, are provided.

For station lists and expedition details, see Moosa.

\footnotetext{
$\left.{ }^{1}\right)$ Marine biologist at O.R.S.T.O.M. - Laboratoire de Zoologie (Arthropodes) du Museum National d'Histoire Naturelle et Laboratoire d'Oceanographie et de Carcinologie de TEcole Pratique des Hautes Etudes, 61 rue de Buffon, PARIS 75005. PRANCE.
} 
In the species descriptions the carapace length is the distance from orbital margin to posterior dorsal margin of the carapace.

Part of the material examined during this study will be registered at the Lembaga Oseanologi Nasional in Jakarta, and part at the Museum National d'Histoire Naturelle in Paris.

The material for this study was kindly entrusted to me by Professor J. Forest of the Museum National d'Histoire Naturelle, who- participated in the CORINDON II expedition, and Dr. M. Kasim Moosa of the Lembaga Oseanologi Nasional, who was in charge of the scientific trawling programme during the CORINDON IV expedition.

Dr. R.W. Ingle and Miss Ann Gumey assisted me at the British Museum and arranged the loan of the Solenocera specimens.

Dr. D. Platvoer of the Zoologisches Museum of Amsterdam, Mrs. van der Merwe of the South African Museum, Dr. B.C. Ivanov of VNIRO and Professor Hoo Soon Kim of the University of Seoul also kindly loaned material.

M.M. Gaillard prepared the illustrations.

Dr. I. Perez Farfante reviewed the manuscript.

I am grateful to all of them.

Family BENTHESICYMIDAE

Genus Benthesicymus Bate, 1881

Benthesicymus investigatoris Alcock \& Anderson, 1899

Benthesicymus investigatoris, De Man, 1911, p. 14; 1913, pi. 1, fig, 1, $1 \mathrm{a}$ - b. - Crosnier, 1978, p, 21, fig. 7c-d, 8c - d, 9, 10 .

Material: CORINDON II — St, 321, $1080 \mathrm{~m}$ : U 24 mm env.; $1522 \mathrm{~mm}$. - St. 240, $675 \mathrm{~m}: 1916.8 \mathrm{~mm}$.

Thelycum in female $22 \mathrm{~mm}$ cl, with posterior border of plate of sternite XIII with distinct median notch as figured by DE MAN (1913, pl. 1, fig, la); notch hardly noticeable on the other female.

This species has a very wide distribution in the Indo-West Pacific and has been collected from off Japan to Hawaii and the East African coast. It has been recorded previously in Indonesia (DE MAN, 1911).

Genus Gennadas Bate, 1881

Gennadas scutatus Bouvier, 1906

Gennadas scutatus, Crosnier, 1978, p. 43, fig. 17a, 19c.

Gennadas clavicarpus, De Man, 1907, p. 144 (partly) ; 1911, p. 19 (partly) ; 1913, pi. 1, fig. 3f, 3g; pi. 2, fig. 3K. 


\section{PENAEGID SHRIMPS}

Material: CORINDON II — St. 286, $1710 \mathrm{~m}$ : 1 के $6 \mathrm{~mm}$.

This widespread species occurs in the Atlantic, Indian and Pacific oceans. It has been recorded from Indonesia by De Man as G. claviowrpus. Specimens were probably collected during the ascent of the trawl.

\section{Family ARISTEIDAE}

Genus Aristaemorpha Wood Manson, 1891

Aristaeomorpha foliacea (Risso, 1827)

Aristaeomorpha foliacea, Crosnier, 1978, p. 54, fig. 23 - 24.

Aristaemorpha rostridentata, Balss, 1925, p. 221, fig. 1-2.

Material: CORINDON IV - St. IV 1, 400 - $300 \mathrm{~m}: 2$ o 18.2 and $28.5 \mathrm{~mm}$; 4 万 29.9 to $32.8 \mathrm{~mm}$. - St. VI 1, $504 \mathrm{~m}: 1$ o $26.6 \mathrm{~mm}$.

This widely ranging species has been recorded from Indonesia as A. rostridentata. It has been collected in the Indo-West Pacific at depths between 61 and $750-810 \mathrm{~m}$.

Genus Aristeus Duvernoy, 1840

\section{Aristeus virilis (Bate, 1881)}

Aristeus virilis, De Man, 1911, p. 27; 1913, pi. 2, fig. 6, 6a. - Crosnier, 1978, p. 61, fig. 25a - b, 26a - b.

Material: CORINDON II — St. 209, 487 - $497 \mathrm{~m}$ : 6327.2 to $33.6 \mathrm{~mm}$. St. 214,592 - $595 \mathrm{~m}$ : 5 juv.; 7 ๙ 27.9 to $32.8 \mathrm{~mm}$; 4 o 25.9 to $45.2 \mathrm{~mm}$. St. 217, 447 - $470 \mathrm{~m}: 1$ ^ $31.4 \mathrm{~mm}$. - St. $240,675 \mathrm{~m}: 1$ + $44.2 \mathrm{~mm}$. St. 276,395 - $450 \mathrm{~m}$ : 16 乃 24.5 to $33.6 \mathrm{~mm} ; 24$ ㅇ 24.5 to $48.4 \mathrm{~mm}$.

CORINDON IV —. St. II 1, 550 - $546 \mathrm{~m}: 1$ ○ $18.0 \mathrm{~mm} ; 1$ + 20.7 mm. - St. VI 1, $504 \mathrm{~m}: 1$ o $29.0 \mathrm{~mm} ; 2$ + 36.8 and $37.5 \mathrm{~mm}$.

In the 12 specimens examined the fifth pereopods bear several photophores, their number varying from 11 to 14 on the carpus, 12 to 15 on the propodus and 6 to 8 on the dactyl. In this respect the Indonesian specimens are similar to those from Japan and not much different from the Madagascar specimens (see CROSNIER 1978, p. 65).

This species has a very wide distribution in the Indo-West Pacific; it has been found off Madagascar, Japan and New Caledonia; and has been reported previously from Indonesia. Specimens heve been collected at depths between 238 and $900 \mathrm{~m}$, but the species seems to occur mostly between 450 and $700 \mathrm{~m}$. 


\section{ALAIN CROSNIER}

Aristeus mabahissae Ramadan, 1938

Aristeus mabakissae, Crosnier, 1978, p. 65, fig. 25c - f, 26c - f.

Aristeus semidentahts, Balss, 1929, p. 224 (partly). Non Bate, 1881.

Material: CORINDON IV — St. VI 1, $504 \mathrm{~m}$ : 1 乃 $31.2 \mathrm{~mm}$; 1 o $42.8 \mathrm{~mm}$.

The fifth pereopods bear 9 photophores on the propodus, 11 or 12 on the carpus and from 4 to 6 on the dactyl.

This species is known from off Madagascar, Maldives, Indonesia and New Caledonia, at depths between 366 and $1097 \mathrm{~m}$.

\section{Aristeus sewjidentaPus Bate, 1881}

Aristeus semidentatus, De Man, 1911, pp. 6, 29; 1913, pi. 2, fig. 7. Crosnier, 1978, p. 68, fig. 26g.

Material: CORINDON IV - St. I 1, 562 - $525 \mathrm{~m}$ : 6 ex. 11.5 to $16.0 \mathrm{~mm}$. St. I 2, 547-507 m: 14 ex. 12.5 to $20.5 \mathrm{~mm}$. - St. Ill 1, 550-546 m: 7 ex. 14.0 to $21.5 \mathrm{~mm}$.

All the specimens are small and damaged. They are identified as sendentatus from the arrangement of photophores on the remaining pereopods.

This species has been reported off Indonesia, Madagascar, India, Kermadec Islands and Hawaii, and has been found at depths between 350 and $1100 \mathrm{~m}$.

Genus Pseudaristeus Crosnier, 1978

Pseudaristeus sp.

Material: CORINDON II - St. 286, $1710 \mathrm{~m}: 1$ ๙ $37.8 \mathrm{~mm}$.

This specimen seems to be different from crassipes (Wood Mason, 1891) and from sibogae (De Man, 1911). It can be distinguished by the following characters:

- body without setae (this is unlikely to have been caused by rubbing in the trawl during sampling);

- median plate of sternite XIII without setae and narrower than those of crassipes and sibogae;

- pereopods without setae. Ocular peduncles robust, closer to those of crassipes.

This specimen probably belongs to a new species. The genus Pseudaristeus needs to be revised; it is necessary, for example, to define the status of P. gracilis (Bate, 1888) and to check, as KEMP \& SEWELL (1912) 


\section{PENAEOID SHRIMPS}

have suggested, if the material from the Indian Museum, identified as crassipes, contains two different forms. Dr. I. Perez Farfante has begun working on a revision of this genus and the Corindon specimen will be sent to her.

\section{Family SOLENOCERIDAE}

Genus Haliporus Bate, 1881

Haliporus taprobanensis Alcock \& Anderson, 1899

Haliporus taprobanensis, Crosnier, 1978, p. 97, fig. 34 - 35, 39a, 40a, 42a. Hymenopenaeus kannemeyeri, Kensley, 1977, p. 27, fig. 7A-F. Material: CORINDON II — St. 240, $675 \mathrm{~m}: 1$ i $57.5 \mathrm{~mm}$. CORINDON IV - St. IIII 1: 1 क $34.2 \mathrm{~mm}$.

To date, this species has been collected in the south of India at depths between 700 and $1200 \mathrm{~m}$, off Madagascar between 700 and $1200 \mathrm{~m}$ and Natal (as Hymenopenaeus kannemeyeri).

\section{Genus Hadropenaeus Perez Farfante, 1977}

Hadropenaeus lucasi (Bate, 1881)

Haliporus lucasii, De Man, 1911, p. 43.

Hadropemws lucasi Perez Farfante, 1977, p. 327, fig. 9, 16, 44c, 53 - 55Hymemopenaeus lucasi, Crosnier, 1978, p. 115, fig. 37f-h, 39c, 40c, 42d, 44, 46a.

Material: CORINDON IV —St. VI 1, 400-300 m; 2 \& 29.0 and $32.2 \mathrm{~mm}$. — St. V 2, 250 - $244 \mathrm{~m}: 4$ o 14.3 to $26.1 \mathrm{~mm} ; 5$ i 25.0 to $29.6 \mathrm{~mm}$.

This species has a very wide distribution in the Indo-West Pacific; it has been reported from off Madagascar to Japan, Hawaii and Indonesia, and collected at depths between 180 and $600 \mathrm{~m}$.

Genus Haliporoides Stebbing, 1914

Haliporoides sibogae (De Man, 1907)

Haliporus sibogae De Man, 1907, p. 138; 1911, pp. 7, 38; 1913, pi. 3, fig. $10 \mathrm{a}-\mathrm{b}$, pi. 4, fig. 10c - q.

Hymenopenaeus sibogae, Crosnier, 1978, p. 104, fig. 36a, 38d, $41 \mathrm{a}$.

Material: CORINDON II — St. 209, 487 - 497 m: 1 o 29.4 mm. — St. 276, $395-450 \mathrm{~m}: 8$ त 29.3 to $31.9 \mathrm{~mm}$; 5 ㅇ 36.8 to $43.5 \mathrm{~mm}$. 
CORINDON IV - St. I 1, 562 - $525 \mathrm{~m}: 2$ 44.0 and $44.5 \mathrm{~mm}$. — St. I 2, 547 - $507 \mathrm{~m}: 3$ o 40.3 to $42.2 \mathrm{~mm}$. - St. II 1, $483-315 \mathrm{~m}: 1$ ๙ $30.0 \mathrm{~mm}$. - St. Ill 1, 550-546 m: 2 31.5 and $32.2 \mathrm{~mm} ; 4 \$ 36.0$ to $39.6 \mathrm{~mm}$. - St. Ill 2, 500 - $375 \mathrm{~m}: 1$ $139.5 \mathrm{~mm}$. - St. IV 1, $400-300 \mathrm{~m}$ : 2 41.0 and $43.5 \mathrm{~mm}$. - St. VI 1, $504 \mathrm{~m}: 10^{\text {त }} 24.3 \mathrm{~mm} ; 2$ ㅇ 42.0 and $42.0 \mathrm{~mm}$.

This species, described from specimens collected in Indonesia, has been found in the South China Sea, off Japan, Australia'and New Zealand, at depth between 100 and $1463 \mathrm{~m}$. It seems to occur mostly between 350 and $600 \mathrm{~m}$.

Genus Hymenopenaeus Smith, 1882

Hymenopenaeus neptunus (Bate, 1888)

Halvporm neptmim Bate, 1888, p. 291, pi. 42, fig. 3 - ? De Man, 1911, p. 37.

Hymenopenaeiis neptunus, Crosnier \& Forest, 1973, fig. 86e - f, 87d.

Material: CORINDON II - St. 231, 1080 m: 1 ๙ $16.5 \mathrm{~mm} ; 3$ i 14.3, 19.1 and $23.2 \mathrm{~mm}$. - St. 241, $1525-1550 \mathrm{~m}: 1$ \% $11.1 \mathrm{~mm}$.

Comparison of this material with the type specimens of $H$. furici Crosnier (1978, p. 127, fig. 39f. 40f, 42f, 43d, 46f-h) confirms the validity of furici which is closely related to neptunus.

Identification of the Siboga specimen, described as neptunus by De Man (1911, p. 37) has been discussed by CROSNIER (1978, p. 129).

This species is known from the Philippines, Indonesia and India (Bay of Bengal) at depths between 1463 and $3197 \mathrm{~m}$.

Hymenopenaeus halli Bruce, 1966

Hymenopenaeus halli, Crosnier, 1978, p. 120, fig. 39d, 40d, 42c, 43b, 45a-d, 46b-c.

Hcsliporus obliquirustris, De Man, 1911, p. 36, Non Bate, 1881.

Material: CORINDON II — St. 276, 395-450 m: 1 ô $16.8 \mathrm{~mm}$.

This species is known from the South China Sea, Indonesia (Great Kei Island: specimen misidentified by De Man, 1911, p. 36, as H. obliquirostris - see CROSNIER, 1978, p. 123) and Madagascar, at depths between 540 and $910 \mathrm{~m}$. 
PENAEOID SHRIMPS

Hymenopenaeus propmquus (De Man, 1907)

Haiiporus propinquus De Man, 1907. p. 140; 1911, p. 33; 1913, pi. 3,fig. 9. Hymenopenaeus propinquus, Crosnier, 1978, p. 124, fig. 39c, 40c, 42e, $43 \mathrm{c}, 45 \mathrm{e}-\mathrm{h}, 46 \mathrm{~d}-\mathrm{e}, 47 \mathrm{a}$.

Material: CORINDON II — St. 276, 395 - $450 \mathrm{~m}: 1$ $20.3 \mathrm{~mm}$. - St. 290, 779 - $798 \mathrm{~m}: 1$ \% $17.9 \mathrm{~mm}$.

CORINDON IV - St. I 2, 547 - 507 m: 1 + 22.6 mm. - St. III $1,550-546 \mathrm{~m}: 3$ 20.7 to $21.8 \mathrm{~mm}$.

Only female specimens of this species have been collected which makes it difficult to distinguish from $H$. aequalis. A distinguishing character is the shape of the transverse protuberance between the fourth pereopods, being rounded from front to back and regularly covered with setae in propinquus, while angular and without setae on the posterior half in aequalis.

$H$. propinquus has been previously recorded from Indonesia. It was collected off the Maldives, in the Gulf of Aden, off Zanzibar, Madagascar and Reunion Island, at depths between 510 and $1200 \mathrm{~m}$.

Hymenopenaeus aequalis (Bate, 1881)

Haliporus aequalis Bate, 1888, p. 285, pl. 41, fig. 1 - De Man, 1911, p. 32; 1913, pl. 2, fig. 8, 8a.

Hymenopenaeus aequalis, Crosnier \& Forest, 1973, fig. 86c - d, 87h. Material: CORINDON II — St. 209, 487 - $497 \mathrm{~m}$ : 2o 13.2 and $13.3 \mathrm{~mm}$; 9 13.0 to $15.4 \mathrm{~mm}$. - St. 214, $592-595 \mathrm{~m}: 2$ o 12.5 and $13.1 \mathrm{~mm}$, , St. 217,447 - 470 m: 1913.6 mm. - St. 276,395 - 450 m: 5 o 13.5 to $14.7 \mathrm{~mm} ; 3$ ㅇ 14.5 to $15.7 \mathrm{~mm}$.

CORINDON IV - St. I 1, 562-525 m: $1 \delta^{\lambda}$ damaged; 1 क $12.3 \mathrm{~mm}$. - St. Ill 1, 550 - $546 \mathrm{~m}$ : 4 o 13.0 to $18.0 \mathrm{~mm} ; 22$ o 13.5 to $23.5 \mathrm{~mm}$. - St. IV 1, $400-300 \mathrm{~m} ; 3$ o 14 to $18 \mathrm{~mm} ; 8$ o 19.9 to 23.4 mm. - St. IV 1, $504 \mathrm{~m}: 1$ ○े $19.0 \mathrm{~mm} ; 5$ 20.1 to $21.5 \mathrm{~mm}$.

This species has been previously reported from Indonesia; it is also known from the Arabian Sea, Shri Lanka, the Andaman Sea, Hawaii and Japan, at depths between 200 and $1367 \mathrm{~m}$. 
Genus Cryptopenaeus de Freitas, 1979

Cryptopenaeus clevai sp. nov.

Figures la - b, 2a-e, 3a

Material: CORINDON IV — St. IV 1, 400 - 300 m: 1 i $53.8 \mathrm{~mm}$ holotype. Description: Carapace apparently smooth but showing some small widely separated depressions near the dorsal margin of rostrum and orbital border, the pterygostomian area and the anterior part of branchial area; these depressions correspond with the insertion of short setae, most of which have been torn out, probably during trawling.

Rostrum rather short, not quite reaching end of second antennular segment; dorsal margin strongly concave with 3 teeth; 4 teeth situated at regular intervals behind orbit; ventral margin strongly convex.

Postorbital carina high and conspicuous, almost reaching posterior border of carapace; without any notch behind last postrostral tooth, and dorsal border without any depression, longitudinal sulcus or bifurcation.

Carapace with antenna!, postorbital, hepatic and pterygostomian spines. Antennal spine small; the three others longer, subequal. Cervical sulcus accompanied by sharp carina posteriorly, ending far before dorsal border of carapace. Hepatic carina interrupted by broad hepatic sulcus, with anterior end strongly curved, forming a prominent lobe on anterior part of pterygostomian area. No vertical sulcus, nor carina, behind hepatic sulcus, except a short branchiocardiac carina.

Eyes well developed with peduncles slightly wider than long when seen from above.

Antennular peduncle almost as long as the scaphocerite. Antennular flagella cylindrical; only one superior flagellum undamaged, its length equal to 1.25 that of carapace and 2.75 that of antennular peduncle.

Stylocerite not reaching to distal margin of eye. Mouth parts (fig. 2a e) typical for Solenoceridae. Endopodite of third maxilliped longer than scaphocerite by length of last segment.

Distribution of branchiae, epipodites and exopodites summarized in Table 1; same as for the genera Haliporoicles, Hadropenaeus and Hymenopenaeus. 


\section{PENAEOID SHRIMPS}
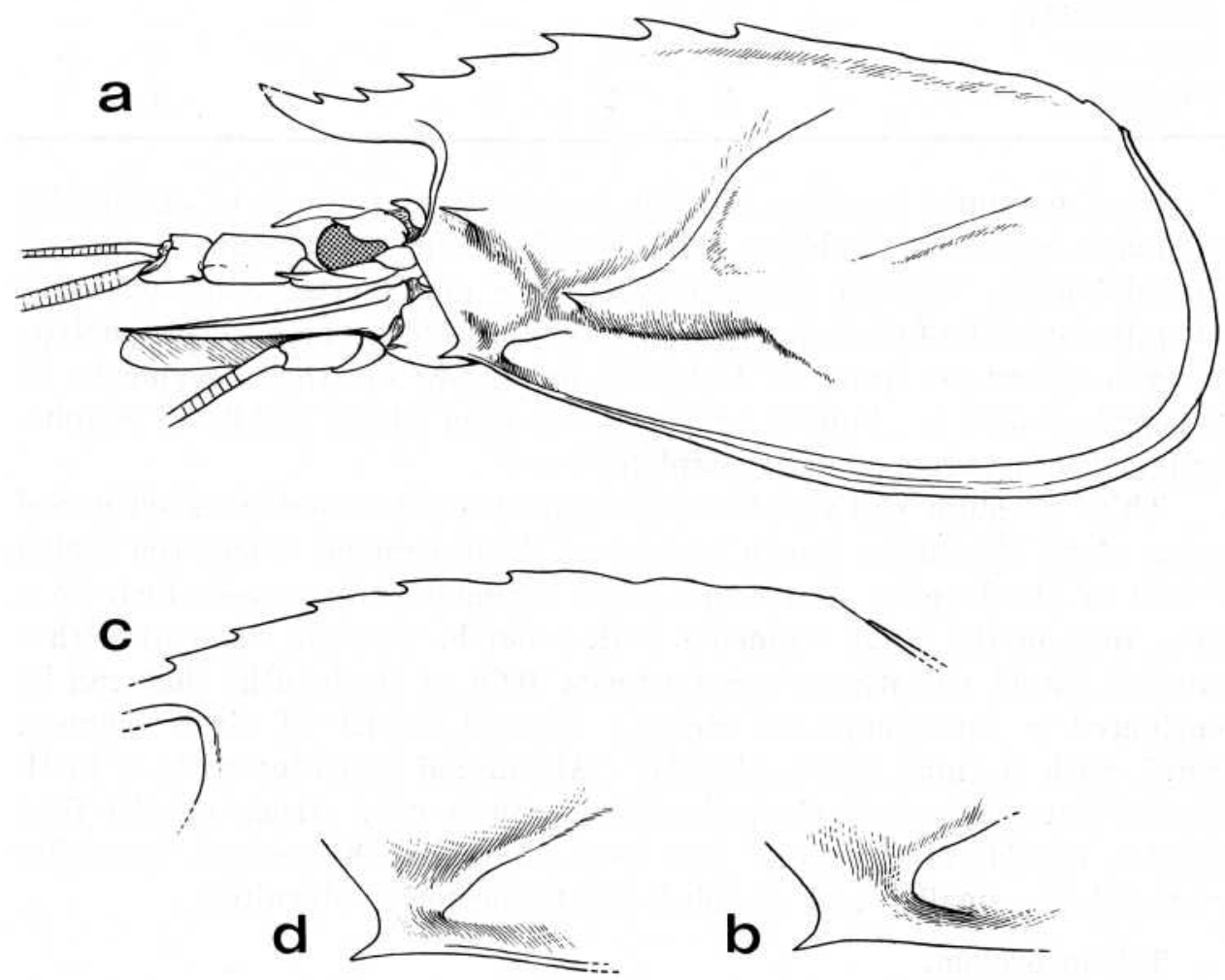

Figure la - b. Cryptopenaeua clevai sp. nov., $\$ 53.8 \mathrm{~mm}$, holotype, CORINDON IV, st. IV 1: a. cephalothorax, lateral view; b. anteroventral part of carapace.

Figure 1c-d. Cryptopenaeus catherinae de Freitas, 1979, \& $68.2 \mathrm{~mm}$, holotype, $25^{\circ} 00^{\prime} \mathrm{S}-35^{\circ} 21^{\prime} \mathrm{E}$ (Mozambique), $500 \mathrm{~m}$ : c, dorsal border of carapace; $\mathrm{d}$, anteroventral part of carapace. 
Table 1. Distribution of branchiae, epipodites and exopodites in Cryptopenaeus clevai.

\begin{tabular}{lrrrrrrrr}
\hline & \multicolumn{3}{c}{ Maxillipeds } \\
\hline & I & II & III & I & II & III & IV & V \\
Pleurobranchiae & - & - & 1 & 1 & 1 & 1 & 1 & 1 \\
Arthrobranchiae & 1 & 2 & 2 & 2 & 2 & 2 & 2 & - \\
Podobranchiae & - & 1 & - & - & - & - & - & - \\
Epipodites & 1 & 1 & 1 & 1 & 1 & 1 & 1 & - \\
Exopodites & 1 & 1 & 1 & 1 & 1 & 1 & 1 & 1 \\
\hline
\end{tabular}

First pereopod reaching slightly beyond first segment of antennular peduncle; basis and ischium armed with a long subterminal spine on ventral border. Second pereopod with only one shorter spine on basis, not quite reaching extremity of scaphocerite. Third pereopod incomplete, without spines on basis or ischium; no spines on these segments in pereopods 4 and 5. Fourth pereopod reaching about middle of scaphocerite. Fifth pereopod not complete.

Third through sixth abdominal segments with a well marked dorsal carina along the entire length, except on third segment where the carina is 0.80 of the length. Carina or sixth segment ending posteriorly in a spine, and on the other segments with a notch. Second segment with a rounded dorsal elevation along posterior 0.66 of its length, that can be considered a forerunner of carina. Ventral border of sixth segment armed with a small spine distally. Abdominal sternites with a tooth situated between paired pleopods; this tooth is very strong on the first sternite, considerably smaller but very sharp on the second, becoming progressively smaller and rounded on the posterior sternites.

Telson broken.

Thelycum (fig. 3a) with pentagonal elongated plate, on major part of sternite XIV, with two double protuberances covered with setae situated on each side of median axis. Behind these, a smooth, median raised tubercle present. Posterior part of pentagonal plate with two transverse ridges, raised vertically and separated from each other by a semicircular depression. Proximal to pentagon ah plate, there are two protuberances covered with setae, transversely elongated on extreme anterior part of sternite XIV. They are situated just next to the two double protuberances on the penagonal plate, separated from them by a simple split. 


\section{PENAEOID SHRIMPS}

General coloration more or less deep pink; some parts whitish (especially rostrum, scaphocerite, and proximal parts of pereopods and pleopods).

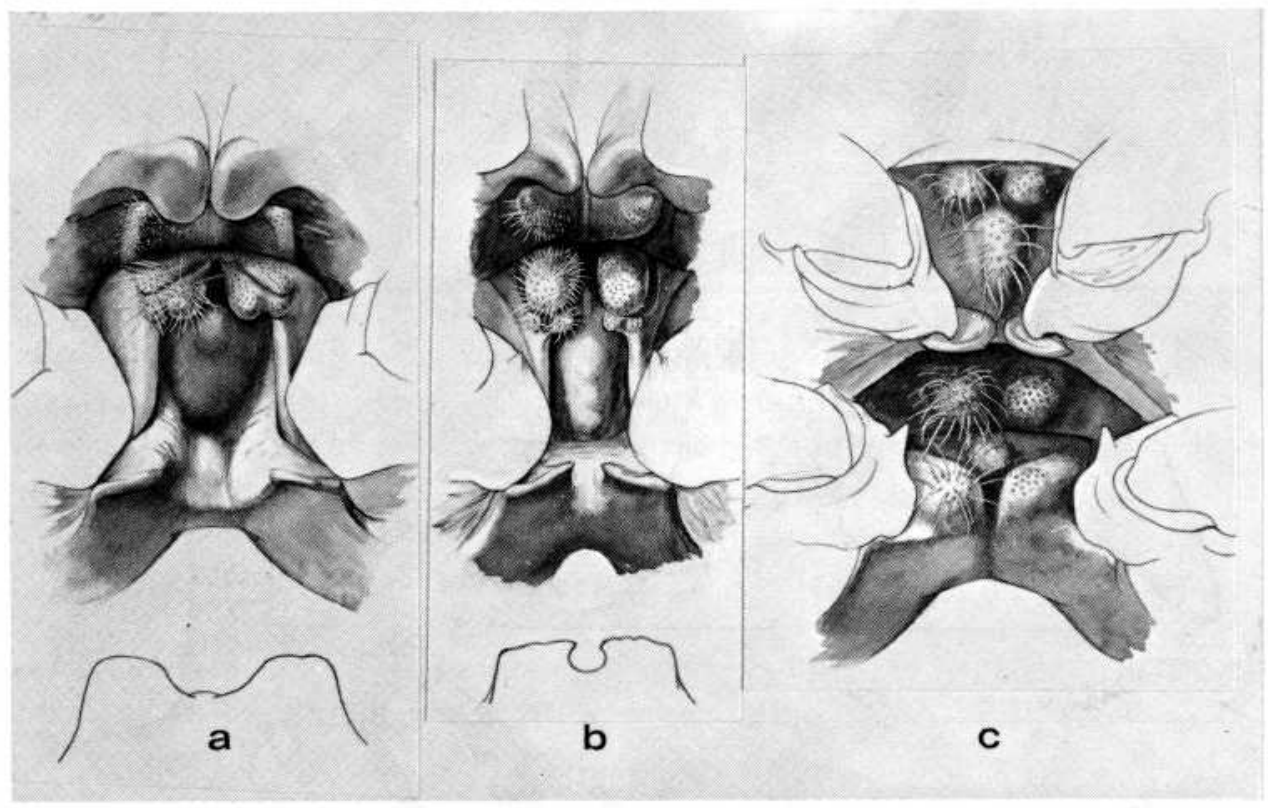

Figure 3. Thelyca, ventral views.

a, Cryptopenaens clevai sp. nov., $ᄋ$ 53.8' mm, CORINDON IV, st. IV 1;

b, Crpytopetweus catherinae de Freitas, 19*79, ㅇ $68.2 \mathrm{~mm}$, hototype, $25^{\circ} 00^{\prime} \mathrm{S}-35^{\circ} 21^{\prime} \mathrm{E}$ (Mozambique), $500 \mathrm{~m}$;

c, Solenocera cf. phuongi Starobogatov, 1972, i $11.6 \mathrm{~mm}$, CORINDON II, st. 208, 149-154 m.

Remarks: Until now the genus Cryptopenaeus was represented by just one species catherinae de Freitas, 1979. Only 5 males and 1 female were recorded, all of them collected off Mozambique, at depths between 310 and $500 \mathrm{~m}$.

We were able to compare our specimen with the female allotype of catherinae.

Cryptopenaeus clevai may be distinguished from catherinae by the anterior part of the hepatic carina. which is relatively straight in catherinae (fig. Id), strongly curved in clevai (fig. 1b).

There are other differences that separate these two species, but to confirm them it would be necessary to examine many more specimens. These additional characters are as follows: 


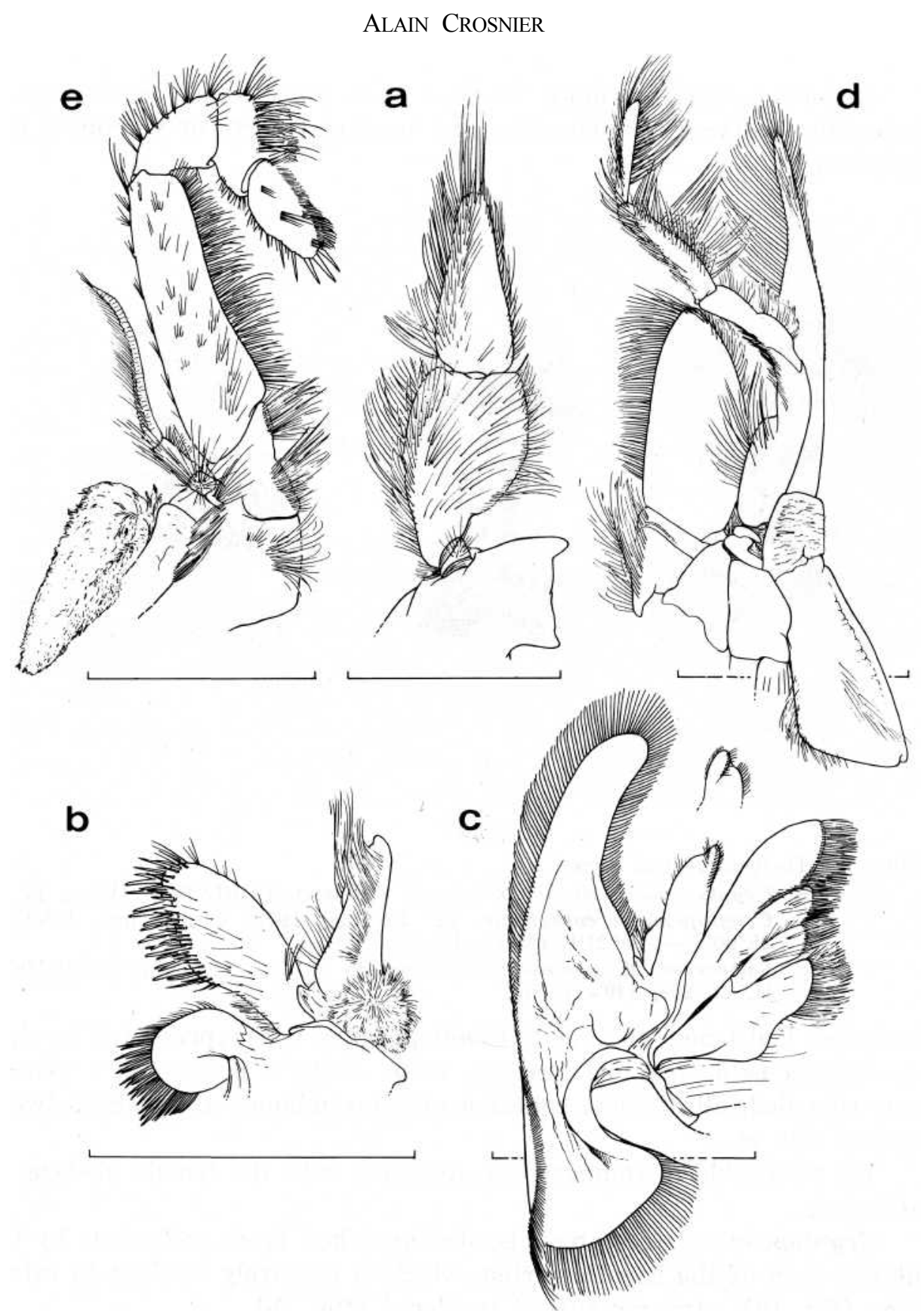

Figure 2. Cryiztopenaeus clevai sp. nov.,, $58.8 \mathrm{~mm}$, holotype, CORINDON IV, st. IV 1: a, right mandible; b, right first maxilla; c, right second maxilla; $\mathrm{d}$, right first maxilliped; e, right second maxilliped. Scale: $1 \mathrm{~cm}$. 


\section{PENAEOID SHRIMPS}

- distinct notch on postrostral carina behind the last tooth in catherinae, absent in clevai. However this notch is pronounced in catherinae males, according to de Freitas' figure, but feeble in the female (fig. 1c);

- antennular flagella longer in catherinae than in clevai (length equal to 3 times that of antennular peduncle in cmtheirkiael, and 2.75 in clevai);

- third maxilliped reaching to the end of scaphocerite in catherinae, but surpassing it by entire length of dactyl in clevai;

- spine present on basis of third pereopod and coxa of fifth perepod in catherinae, absent in clevai;

- dorsal carina pronounced on second abdominal segment in cathe rinae, just visible (weak and rounded) in clevai;

- thelyca very similar in both species; however that of catherinae differs from that of clevai in bearing a longitudinal crest with rounded tip on pentagonal plate (instead of a raised tubercle); smaller setose protuberances in front of pentagonal plate; anteriormost protuberances of sternite XIV larger and rounder; vertical lateral elevations ion posterior border of trapezoid plate bearing a tooth in the internal angle (fig. $3 a-b)$.

This species is dedicated to Mr. R. Cleva, a technician at the Laboratory of Zoology, at the Museum National d'Histoire Naturelle, who, in the course of his laboratory duties, undertakes with great devotion and competence, much essential but often tedious work.

Genus Solenocera Lucas, 1849

Solenocera comata Stebbing, 1915

Solenocera comata, Crosnier 1978, p. 138, fig. 48b, 49b, 50d - f, 51 b - c, $52 \mathrm{~b}, 55 \mathrm{~b}, 58 \mathrm{~b}, 59 \mathrm{e}$.

Material: CORINDON IV — St. V 2, 250-244 m: 3 o $12 \mathrm{~mm}$.

This species has been reported off Madagascar, in the south of China Sea and off Japan, at depths between 55 - $97 \mathrm{~m}$ and 348 - $360 \mathrm{~m}$. It does not seem to have been recorded previously in Indonesia. 
Solenocera ehoprati Nataraj, 1945

Solenocera choprai, Crosnier, 1978, fig. 49g, 51d-e, 52c, 53a -c, 54a - b, 55c, 56a - c, 58c, 59f.

Material: CORINDON II — St. 273, 120-200 m: 1 के 30.2 mm; 2 ㅇ 12.2 and $31.0 \mathrm{~mm}$.

This species is known from off Madagascar, the Gulf of Suez, the Arabian Sea and the Andaman Sea, the Malacca Strait and the South China Sea, at depths between $50 \mathrm{~m}$ and $170-175 \mathrm{~m}$.

Specimens cited 'above are very similar to those reported by Hall (1962, fig. 75) from the Malacca Strait; their postrostral carina is not very high and the posterior border of sternite XIV is slightly sinuous in females (see CROSNIER, 1978, pp. 143-144).

Starobogatov (1972, pp. 363, 384, pi. 2, fig. 6a - c) described $S$. vietnamiensis, a species closely related to choprai. Dr. B.G. Ivanov from VNIRO loaned us three of the type specimens to examine (Pelamida St. 33, n॰53241; St. 34, n53241). These 3 specimens are, in our opinion, S. koelbeli De Man, 1911. The postrostral carina is divided into two branches, not joining posteriorly as described by Starobogatov for vietnamiensis in figure 6a. It would appear that either Starobogatov has two species present in his type collection, or vietnamiensis is a synonym of koelbeli. The holotype would need to be examined in order to resolve this question, but we believe the latter explanation is correct.

If koelbeli and vietnamiensis are synonyms, the female specimen that Starobogatov (1972, p. 361, pi. 2, fig. 9c) has identified as koelbeli probably belongs to an another species.

\section{Solenocera melantho De Man, 1907}

Solenocera melantho De Man, 1907, p. 137; 1911, p. 48; 1913, pi. 5, fig. 12, $12 \mathrm{a}$ - i. - Starobogatov, 1972, p. 34, pi. 2, fig. 8a - d. - Perez Farfante \& Grey, 1980, p. 427, fig. 3b - c, 6a - b, 7a - b.

Solenocera prominentis Kubo, 1949, p. 231, fig. 8V, 14C, 16C, 20M, 27Q - S, 45A, 66G - H, 72F and L, 80E, 94D - G, 95, 100. - Hoon Soo Kim, 1977, p. 99, fig. 12A-F, 13A - J, pi. 41, fig. 1. — Lee \& Yu, 1977, p. 47 , fig. 29 - 30.

Non Solenocera melantho, Lee \& Yu, 1977, p. 45, fig. 27-28 = probably S. koelbeli De Man, 1911. 
Material: CORINDON II — St. 273, 120-200 m: 1 ๙ $226.8 \mathrm{~mm} ; 1$ 우 $32.3 \mathrm{~mm}$.

De Man's type specimens were collected in Indonesia and the material described here agrees closely with them although the pereopods are a little shorter than those of the type figured by DE MAN (1913, pl. 5, fig 12), and the dorsolateral lobules of the petasma are armed with 3 or 4 spines, not 9 to 13 as in the holotype (see DE MAN, 1913, fig. 12g-h, and PEREZ FARFANTE \& GReY, 1980, fig. 6a -b).

The specimens of $S$. prominentis Kubo (1949) from Japan can be distinguished from those of typical melantho by the shorter pereopods and smooth dorsolateral lobules of the petasma, Prof. Hoon Soo Kim, University of'Seoul, kindly allowed us to examine one male and one female of prominentis collected in Korea, which confirmed these differences. It is interesting to notice that all the lobules of the petasma in the Korean male are less spiny than that of the Indonesian male: the Korean male have 13 and 14 spines on the ventromedian lobules while the Indonesian specimen has 16 and 17,9 and 11 spines on the ventrolateral lobules instead of 13. The antennulae are damaged and, therefore, it is impossible to make my comparisons.

The Korean and Indonesian specimens are alike in all other respects and I consider the cited differences may characterize geographically separated populations, but that they do not correspond to different new species or subspecies. I agree with STAROBOGATOV (1972, p. 361) on the synonymy of promiiientis and melantho.

It should be noted that specimens of S. halli Starobogatov, 1972, collected in the Malacca Strait, were misidentified by HALL (1962, fig. 74) as S. melantho. S. halli is closely related to melanthog koelbeli De Man, 1911, and australiana Perez Farfante \& Grey, 1980.

Taking into account the confusion between these species, it is difficult to define the geographical distribution of melantho. This species is definitely known from off Korea, Japan and Taiwan (as prominentis), Philippines and Indonesia, occurring at depths between 150 and $400 \mathrm{~m}$.

Solmocera cf. waltairensis Georges \& Muthu, 1970

Figures $4 \mathrm{a}, 7 \mathrm{a}$.

Material: CORINDON II - St. 205, $49 \mathrm{~m}$ : 1 ก $6.9 \mathrm{~mm} ; 396.9$ to $8.1 \mathrm{~mm}$. - St. 295, 51-54 m: 1 o $7.1 \mathrm{~mm}$. 
All the collected specimens are damaged, all having lost their antennulae and most of their legs. They are also very small.

We have compared these specimens with those from Madagascar identified as waltairensis (CROSNIER, 1978, p. 165, fig. 49f, 52g, 55g, $57 \mathrm{~d}, 59 \mathrm{c}, \mathrm{j}, 62 \mathrm{~d}-\mathrm{f}, 63 \mathrm{e}-\mathrm{f})$. They are similar but show some small differences; the following characters are found in the Indonesian specimens :

- anterior part of hepatic carina slightly more vertical;

- 6 to 8 spines on accessory lobules of petasma (9 to 11 in Mada gascan specimens), 19 to 21 on dorsolateral lobules (instead of 13 to 17). In the Indonesian specimens the spines are spread over a wider area, reaching to below apex of ventrolateral uobules (not in Madagascan specimens). Ventromedian lobules less angular (more curved); one male with 15 spines; another with 24 . In the Indonesian specimens the spines on the accessory and dorsolateral lobules are more like those in the types of waltairensis (GEORGES \& MUTHU, 1970, p. 292, fig. 1-4), than the Madagascan specimens although they are stronger and spread over a wider area on the dorsolateral lobules;

- sternite XIV in the female is produced posteriorly to form two large protuberances, and anteriorly forms four transverse ele vations. There does not appear to be a median elevation anterior to the large protuberances as is found in the Madagascan speci mens and the waltairensis holotype (this character, however is difficult to ascertain in our small specimens).

The Indonesian specimens have 7.8 or 9 rostral and postrostral teeth. The second pereopod surpasses the scaphocerite by the entire length of the dactyl.

\section{Solenocera cf. phuongi Starobogatov, 1972}

Figures 3c, $4 b$.

Material: CORINDON II - St. 208, 149-154 m: 1 $11.6 \mathrm{~mm}$.

This specimen is close to bedokemis HaLL (1962, pi. 3, fig. 78, $78 \mathrm{a}-\mathrm{c}$ ) and phuongi StARoBogatov (1972, p. 366, pi. 3, fig. 12a-b) by the possession of 7 rostral and postrostral teeth and also the hepatic carina which runs in an almost straight line with the inferior part of hepatic sulcus. It seems to be closer to phuongi by the arrangement of protuberances and tubercles on the thelycum, but the pereopod lengths 


\section{PENAEOID SHRIMPS}

are different: the first extends as far as 0.68 the length of the scaphocerite compared to 0.33 in phuongi. The second pereopod extends beyond the scaphocerite by the length of the dactyl (unlike that in phuongi where it reaches only to the end of the scaphocerite). The third pereopod also extends beyond the scaphocerite by a little more than twice the length of the propodus, instead of 2.5 times in phuongL

The inferior antennular flagellum is composed of 78 segments. The superior antennular flagellum is 1.8 times the length of the carapace. Only the basis and ischium of the first pereopod are armed with a spine.

S. bedokensis and S. phonngi were both described from single, damaged, females (without antennulae) and the illustrations for both were poor. It is therefore difficult to identify specimens until the two species have been adequately redescribed.

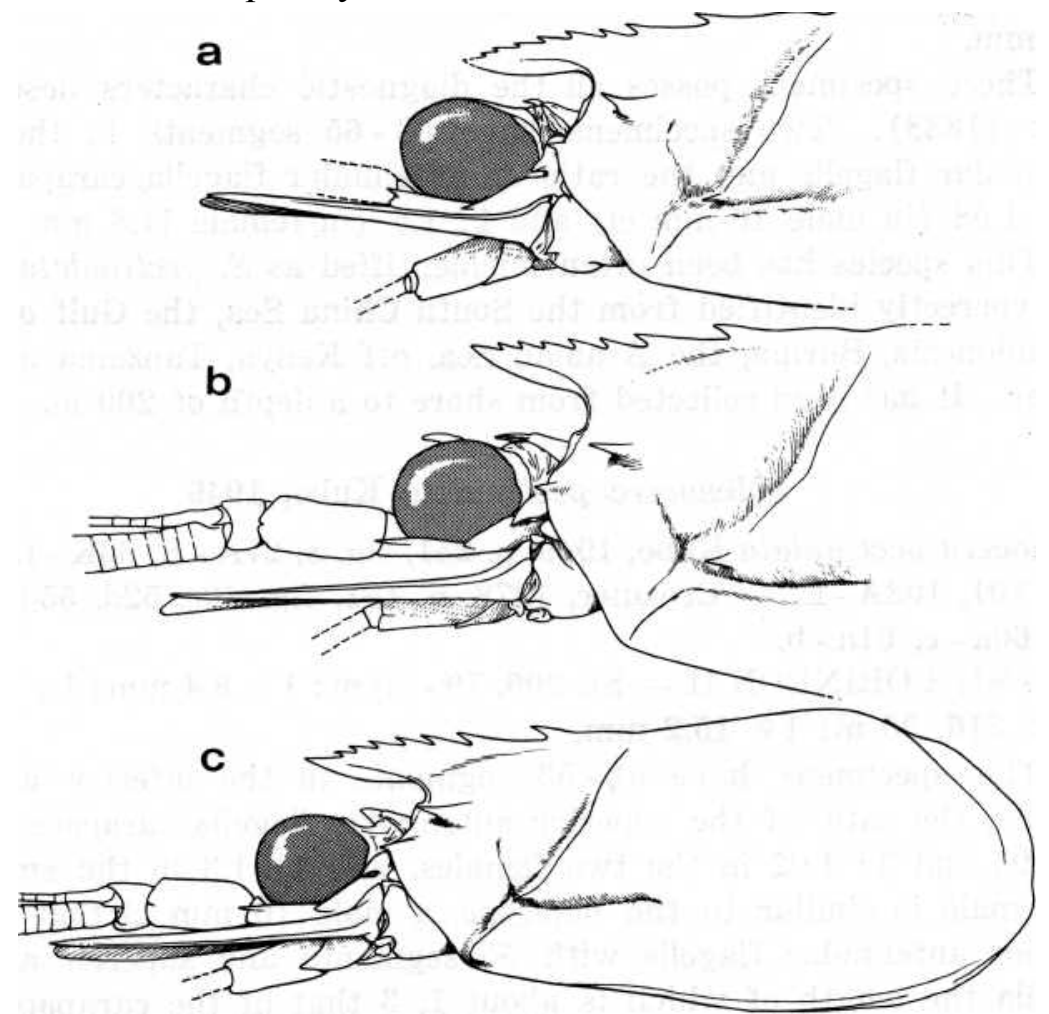

Figure 4. Cephalothoraxes, lateral views.

a, Solenocera cf. waltairensis George \& Muthu, 1970, ^ $6.9 \mathrm{~mm}$, CORINDON II, st, 205, $49 \mathrm{~m}$;

b, Solenocera cf. phuongi Starobogatov, 1972, ㅇ $11.6 \mathrm{~mm}$, CORINDON II, st. 208, $149-1(54 \mathrm{~m}$;

c, Solenocera sp., ơ $9.1 \mathrm{~mm}, \mathrm{CO}^{\prime} \mathrm{RINDON}$ II, st. 273, 120-200 m. 
This is also the case for gurjamovae Starobogatov, 1972, and zarenkovi Starobogatov, 1972, two species closely related to the preceding ones. A total revision of the Solenocera group from the Indo-West Pacific, characterized by the presence of the postorbital, antennal and hepatic spines, and an hepatic carina that is straight anteriorly, would be ideal. This group also includes rathbuni Ramadan, 1938, and waltairensis Georges \& Muthu, 1970. For specific identification the range of variation must be compared and geographical localities taken into consideration.

Solenocera pectinata (Bate, 1888)

Solenocera pectinata, Crosnier, 1978, p. 162, fig. 49d, 52e, 55e, 57b, 59a, h, 60d - f, 61c - d.

Material: CORINDON II — St.295, 51 - $54 \mathrm{~m}$ : 2 ๙ 9.5 and $10.0 \mathrm{~mm} ; 1$ 우 $11.8 \mathrm{~mm}$.

These specimens posses all the diagnostic characters described by BATE (1888). Two specimens have 63-65 segments in the inferior antennular flagella and the ratio of antennular flagella/carapace length is 1: 1.58 (in male $10 \mathrm{~mm} \mathrm{cl}$ ) and 1: 1.5 (in female $11.8 \mathrm{~mm} \mathrm{cl}$ ).

This species has been often misidentified as $S$. pectinulata, but has been correctly identified from the South China Sea, the Gulf of Tonkin, off Indonesia, Burma, the Arabian Sea, off Kenya, Tanzania and Madagascar. It has been collected from shore to a depth of $200 \mathrm{~m}$.

Solenocera pectinulata Kubo, 1949

Solenocera pectinulata Kubo, 1949, p. 251, fig. 8, 27A- B, 66K - L, 72N - T, 83B, 101, 102A - C. - Crosnier, 1978, p. 151, fig. 49c, 52d, 55d, 57, 58d, $59 \mathrm{~g}, 60 \mathrm{a}-\mathrm{c}, 61 \mathrm{a}-\mathrm{b}$.

Material: CORINDON II - St. 206, 79 - 85 m: 1 ก 8.4 mm; 1 ㅇ 14.4 mm. - St. 216, $96 \mathrm{~m}: 1$ ㅇ $15.2 \mathrm{~mm}$.

The specimens have 51 - 53 segments in the inferior antennular flagella, the ratio of the superior antennular flagella/carapace length is 1: 0.95 and $1: 1.02$ in the two females, and 1: 1.3 in the small male. This male is similar to the holotype, a male $10 \mathrm{~mm}$ cl that possesses inferior antennular flagella with 55 segments and superior antennular flagella the length of which is about 1.3 that of the carapace.

The thelycum was figured by CROSNIER in 1978 (fig. 60a) and it should be noted that the two protuberances on the trapezoid plate of sternite XIV often have a larger longitudinal extention than shown in the illustration. 
This species has been reported from off Japan, Indonesia, west coast of India, Kenya, Mauritius Island and Madagascar, from depths between 75 and $350 \mathrm{~m}$, but usually seems to occur mostly above $175 \mathrm{~m}$.

\section{Solenocera sp.}

Figures 4c, $7 \mathrm{~b}$.

\section{Material: CORINDON II - St. 273, 120-200 m: $1 \overbrace{}^{\lambda} 9.1 \mathrm{~mm}$.}

This species falls within the pectinata-pectinulata group. It is probably a new species but with only one male specimens this cannot be confirmed.

The rostrum of this specimen suggests it is close to pectinulata, but the elongate antennular flagella (length equal to 1.65 that of the carapace), the 66 segments in the inferior antennular flagella and the shape of the branchiostegal lobe, place it close to pectinata. The third pereopod is longer than the scaphocerite by 0.33 of the length of the carpus, unlike that of pectinulata in which it is a little more than 0.25 , or that of pectinata in which it is 0.20 of the length of the carpus.

The petasma is similar to that of pectinulata in the shape of the ventromedian lobes, length of setae on the dorsolateral lobes and number of spines (10 to 12) on the accessory lobes; but the'ventrolateral lobes have just one tooth on the distal border of their curved extremity as in pectinata; the remaining length of the curved end is pectinated, a character not present in pectinata or pectinulata.

Solenocera moosai sp. nov.

Figures 5a, 6a, 7c, d, h, i,

Material: CORINDON II - St. 273, 120 - $200 \mathrm{~m}$ : 2 o 15.1 and 17.0 $\mathrm{mm} ; 1521.8 \mathrm{~mm}$. The male specimen $17.0 \mathrm{~mm} \mathrm{cl}$ is the holotype. The other specimens are paratypes.

Description: Carapace glabrous, lacking setae except for some setae close to the superior margin of the rostrum. Rostrum well developed and rather high, with a subhorizontal dorsal margin and a convex ventral margin that is sometimes slightly sinuous at end. Extremity of rostrum very distinct, reaching about 0.80 the length of the cornea. Six rostral and postrostral teeth. First, epigastric, tooth separated from preceding one and situated farther from it than from he cervical sulcus at 0.33 of the distance between the cervical sulcus and orbit. Three teeth behind the orbit, fourth tooth above the orbit. 


\section{Alain CROSNIER}

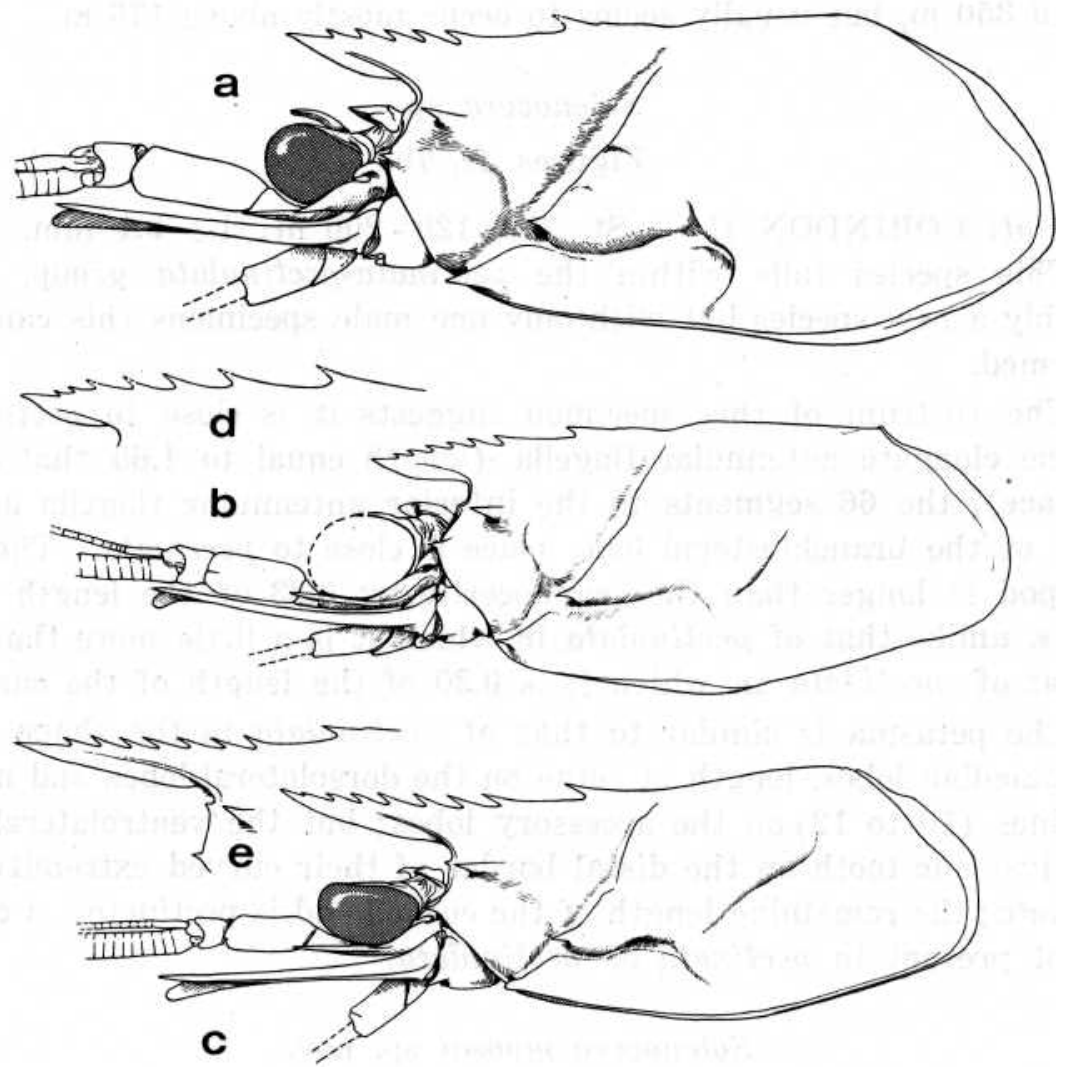

Figure 5a - c. Cephalothoraxes, lateral views:

a, Solenocera moosai sp. nov., ô 17.0' mm, hole type, CORINDON II, st. 273, 120-200 m;

b, Solenocera spinajugo Hall, 1961, ᄋ $12.1 \mathrm{~mm}$, MUSORSTOM I Philippines, st. $45,13^{\circ} 16.0^{\prime} \mathrm{N}-12 \mathrm{O}^{\circ} 23.8^{\prime} \mathrm{E}, 100-180 \mathrm{~m}$, (eye damaged);

c, Solenocera annectens (Wood-Mason, 1891), ô $15.8 \mathrm{~mm}$, CORIN DON II, st. 276, 395-450 m.

Figure 5d - e. Rostrums:

d, Solenocera faxoni De Man, 1807, ᄋ $18.5 \mathrm{~mm}$, holotype, Siboga Exp., st. $254,5^{\circ} 40 ' \mathrm{~S}-13 \mathrm{i}^{\circ} 26^{\prime} \mathrm{E} 310 \mathrm{~m}$;

e, Solenocera annectens (Wood-Mason, 18910, o $20.7 \mathrm{~mm}$, MUSOR STOM II Philippines, st. $25,13^{\circ} 39.0^{\prime} \mathrm{N}-12 \mathrm{O}^{\circ} 42.6^{\prime} \mathrm{E}, 550-520 \mathrm{~m}$.

Postrostral carina only slightly overreaching the dorsal extremity of the cervical sulcus that extends to the dorsal border but does not interrupt the postrostral carina which is only barely depressed at ist level. 
Carapace with antennal, hepatic and postrostral spines.

Hepatic carina ending anteriorly in a very sharp lobe projecting beyond the carapace border. Hepatic sulcus clearly distinct and hepatic area above sulcus and behind spine strongly elevated, posteriorly defined by a conspicuous transverse sulcus. Eyes large.

Antennulae with prosarteraa almost reaching the apex of the rostrum; antennular peduncle slightly shorter than scaphocerite. Superior antennular flagella ending as a filament, with the last 12 segments not flattened but cylindrical, and little longer than the inferior flagella. Ratio of superior flagella/carapace length $1: 1.65$ in male $15.1 \mathrm{~mm} \mathrm{cl}$, and $1: 1.60$ in male $17,0 \mathrm{~mm} \mathrm{cl} ; 1: 1.42$ in female $21.8 \mathrm{~m} \mathrm{mcl}$. These specimens have 92.80 and 77 segments respectivtly the inferior flagellum.

External border of scaphocerite with distal spine reaching the distal margin of lamella.

Third maxilliped surpassing the scaphocerite by the length of the dactyl which is equal to 0.75 the length of the male propodus and 0.66 the length of the female propodus.

First pereopod overreaching the base of scaphocerite by entire length of propodus; basis and ischium armed with a rather long subdistal spine on inferior border. Second pereopod with a spine on basis only, extending to end of scaphocerite. Third, fourth and fifth pereopods without spine. Third pereopod surpassing scaphocerite by entire length of propodus and 0.25 that of carpus. Fourth pereopod exceeding scaphocerite by 0.33 length of dactyl in male (the end of the female). Fifth pereopod very long( length close to 2.85 that of carapace).

Coxae of the five pairs of pereopods each armed with tooth that is well developed on the fifth coxa only.

First two abdominal segments without dorsal carina; third segment with a well marked carina on 0.80 to 0.90 of its posterior length. Last three segments with a carina along their entire length. Carina of third, fourth and fifth segments ending posteriorly in a notch; carina of sixth segment ending in a spine. Abdominal sternites with a tooth between pleopods. Inferior borders of sixth segment armed with a small posterior spine.

Telson length equivalent to 1.3 that of sixth abdominal segment, barely longer than internal uropodal rami and barely shorter than external uropodal rami. External border of external uropodal rami ending in an indistinct tooth. Telson dorsally depressed to form a groove anteriorly, 


\section{ALAIN CROSNIER}

then convex, and armed with a pair of strong, fixed, lateral spines at posterior .0 .70 of its length.

Thelycum (fig. 6a) with a pair of small elevations covered with setae on the anterior part of sternite XIV. Posterior part of sternite XIV trapezoid, entirely smooth with a central protuberance flanked posteriorly by broad, rounded ridges separated caudaly by a longitudinal median sulcus.

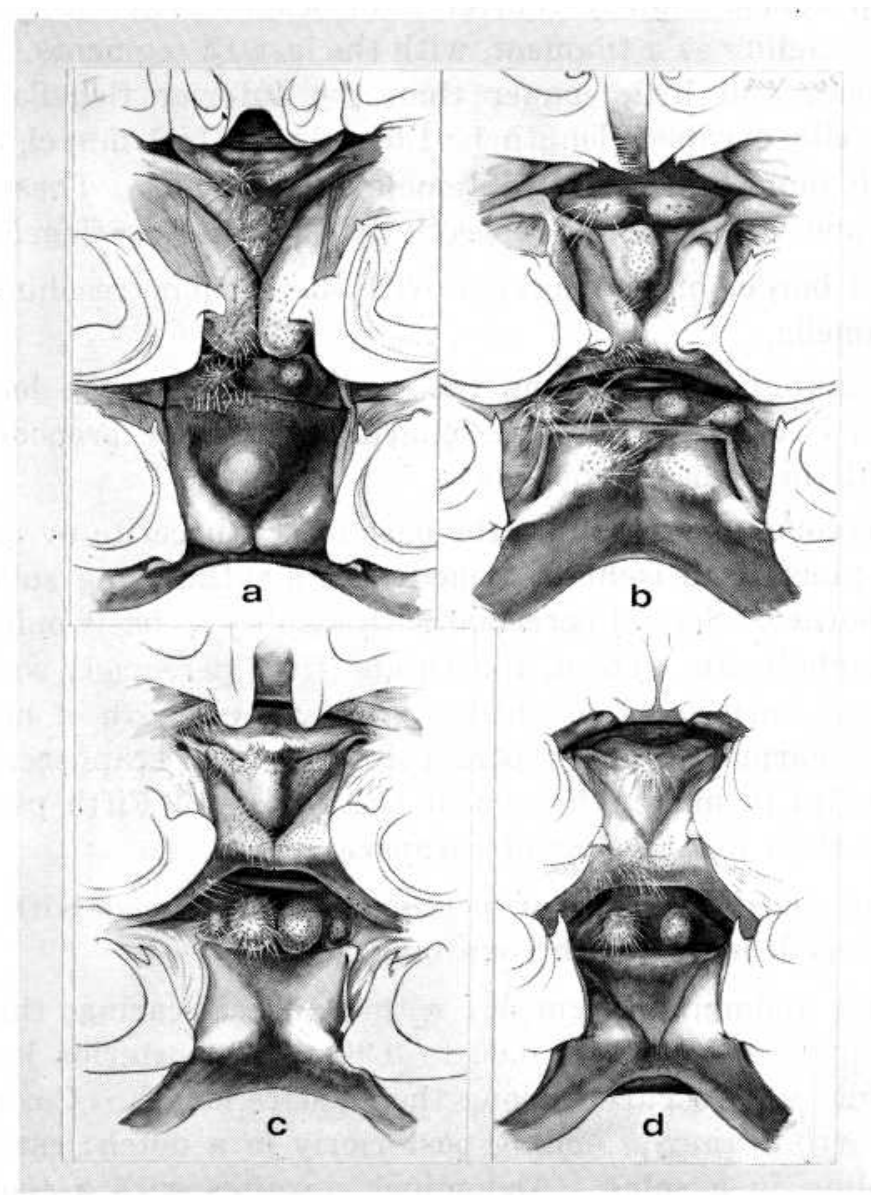

Figure 6. Thelycum ventral views.

a, Solenocera moosai sp. nov., † $21 . \& \mathrm{~mm}$, paratype, CORINDON II, st. 273, 120 - $200 \mathrm{~m}$;

b, Solenocera spinajugo Hall, 1S61, $q 12,1 \mathrm{~mm}$, MUSORSTOM I Philip pines, st. $45,1.3^{\circ} 46.0^{\prime} \mathrm{N}-120^{\circ} 23.8^{\prime} \mathrm{E}, 100-180 \mathrm{~m}$;

c, Solenocera annectens (Wood-Mason, 1891), \$ $20.7 \mathrm{~mm}$, MUSORSTOM II Philippines, st. $2513^{\circ} 39.0^{\prime} \mathrm{N}-120^{\circ} 42.6^{\prime} \mathrm{E}, 560-80 \mathrm{~m}$;

$\mathrm{d}$, idem, $13.6 \mathrm{~mm}$, CORINDON IV, st. I 1, 562-525 m. 


\section{PENAEOID SHRIMPS}

Petasma (fig. 7c - d) with ventromedian, dorsolateral and ventrolateral lobules deeply pectinated. Ventromedian lobules bilobed with 11 to 16 spines on part adjacent to dorsomedian lobules, and 15 to 18 on opposite part. Dorsolateral lobules with 22 to 25 spines and ventrolateral lobules with about 40 . Accessory lobules not well developed, consisting of a membranous fold and unarmed.

Appendix masculina represented on figure $7 \mathrm{~h}-\mathrm{i}$.

Remcvrks: This species is very closely related to S. faxoni DE MAN (1907, p. $136 ; 1911$, p. 52; 1913, pi. 5, fig. 13) described from a badly damaged female collected in Kei Island (Indonesia). Since De Man's description, this species has only been recorded by KUBO (1949, p. 241; fig. 8U, 20P, 27C-E, 45F, 66A-B, 72R and'X, 80C, 97, 98E-G, 100) from off Japan at the depth of $250 \mathrm{~m}$.

I was able to examine the type specimen of faxoni as well as a male and female from Tosa Bay, Japan, and a male misidentified as S. spinajugo Hall, 1961, collected at $19^{\circ} 02^{\prime} \mathrm{N}-112^{\circ} 49^{\prime} \mathrm{E}$ in the collections of the British Museum (Natural History), registration number 1969-862.

S. moosai and S. faxoni have the following characters in common:

- anterior part of hepatic carina forming a sharp branchiostegal lobe with apex extending beyond carapace border;

- hepatic area elevated and limited, apart from hepatic sulcus, by a more or less vertical sulcus starting close to posterior end of hepatic sulcus;

- six rostral and postrostral spines, the last situated far behind the others;

— pereopodal lengths;

- extremity of superior antennular flagellum ending in a cylindrical filament composed of about 12 segments (De Man's figure 13c represents a superior antennular flagellum with a broken end as observed in a faxoni specimen from the British Museum which had one entire superior antennular flagellum). 


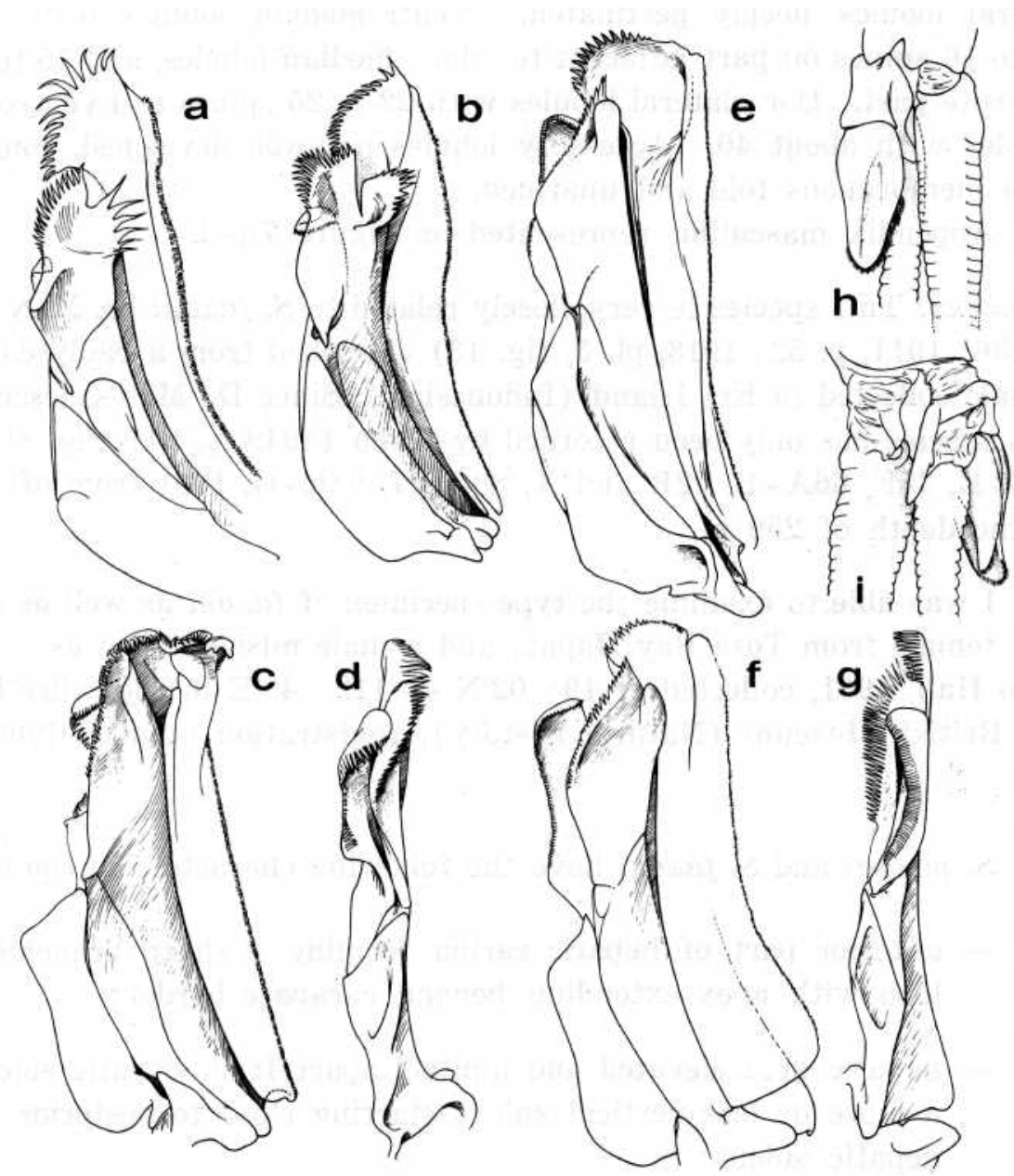

Figure 7a - f. Petasmata, right half, lateral and ventral views.

a, Solenocera cf. waltairensis George \& Muthu, 1970, § 6,9 mm, CORINDON II, st. 205, 49 m;

b, Solenocera sp., ô 9,1 mm, CORINDON II, st. 273, 120-200 m; c - d, Solenocera moosai sp. nov., ô 17.0> mm, halotype CORINDON II, st. 273, 120-200 m;

e, Solenocera faxoni De Man, 1907, ð13.7 mm, Tosa Bay, Japan;

f, Solenocera annectens (Wood-Mason, 1891), ô $15.8 \mathrm{~mm}$, CORIN DON II, st. $276,395-450 \mathrm{~m}$.

Figure 7g. Petasma, left half, ventral view. Solenocera annectens (Wood-Mason, 1891), ơ 17.2 mm, CORINDON IV, st. I 1, 562 - 525 m.

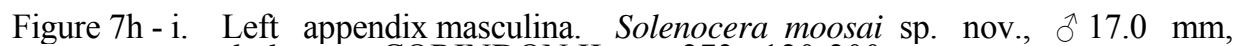
holotype, CORINDON II, st. 273, 120-200 m. 


\section{PENAEOID SHRIMPS}

S. moosai differs from S. faxoni by the following characters:

— distinct dorsal carina on third abdominal segment (totally lacking in faxoni) ;

- antennular flagella much longer. It is difficult to measure preci sely the total length of the antennula because of the damaged flagella in most specimens. However it seems probable that in faxoni the ratio of superior antennular flagella/carapace length is about 1: 15 to $1: 1.30$ and in moosai to about $1: 1.40$ to $1: 1.65$, this ratio decreasing with the size of the specimens. So it is 1: 1.3 in a male faxoni, $11.8 \mathrm{~mm} \mathrm{cl}$, and 1: 1.65 in a male moosai, $15.1 \mathrm{~mm} \mathrm{cl}$. There are 52 to 64 segments on inferior antennular flagella in faxoni, and 77 to 82 in moosai.

- eyes normal in size (rather small in faxoni);

- petasma armed with more developed spines and bilobed ventromedian lobules (entire in faxoni, fig. 7e); accessory lobules not separated and without rounded tips but forming a simple mem branous fold.

Detailed comparison of thelyca is not possible with the material available (the faxoni type specimen is partially damaged) but they appear very similar in the two species: both exhibit paired protuberances covered with setae on anterior part of sternite XIV.

The rostrum exhibit some differences (fig. 5a, 5d); in faxoni the tip is not raised as high and the inferior margin is more sinuous at the extremity. But considering individual variations.

Finally moosai seems to occur at slightly shallower depths than faxoni (120-200 m compared with 250-310 m).

S. spinajugo HALL (1961, p. 81, pi. 17, fig. 1-3) is also closely related to moosai (and so to faxoni). To date this species is known from the type specimen, a female collected in the north Malacca Strait, at a depth of $75 \mathrm{~m}$. A second female specimen from a depth between 100 and $180 \mathrm{~m}$ was collected during the Musorstom I expedition in the Philippines. S. spinajugo is distinguished by the following characters:

- branchiostegal lobe ending in a distinct spine just reaching the anterior border of carapace (fig. 5b); 
- 7 rostral and postrostral spines, rostrum not sharply pointed and with inferior margin convex along its entire length;

- well developed antennular f lagella: ratio of superior flagella/cara pace length is 1: 1.8 in female $12.1 \mathrm{~mm} \mathrm{cl}$. Flagella with 77 segments in our specimens and filamentous distally on a short distance only (fig. 6b) ;

- no spine on basis of second pereopod;

- dorsal carina on third abdominal segment (less marked than in moosai);

- thelycum (fig. 6b) with two conspicuous protuberances on anterior part of sternite XIV covered with setae and partially subdivided; trapezoid posterior part of sternite XIV showing posteriorly two large protuberances covered with setae and anteriorly a very small median elevation also covered with setae.

Finally this species has normal sized eyes and the cervical sulcus, unlike HALL'S observation (1961, p. 82) does not continue from one side of the carapace to the other, but is interrupted near the dorsal line as in the other species described in this study. Postrostral crest is indistinct and therefore does not constitute, a distinguishing character.

Solenocera annectens (Wood Mason, 1891)

Figures $5 \mathrm{c}, \mathrm{e}, 6 \mathrm{c}-\mathrm{d}, 7 \mathrm{f}-\mathrm{g}$.

Parasolenocera annectens Wood Mason in Wood Mason \& Alcock, 1891, p. 276. - Alcock \& McArdle, 1901, pi. 49, fig. 6. - Alcock, 1901, p. 21. Material: CORINDON II — St. 276, 395-450 m: 1 o $15.8 \mathrm{~mm}$.

CORINDON IV - St. I 1, 562-525 m: 1 人ิ $17.2 \mathrm{~mm}$; 1 + $13.6 \mathrm{~mm}$. - St. III, 483 - $315 \mathrm{~m}: 1$ o $15.2 \mathrm{~mm} ; 1$ o $13.1 \mathrm{~mm}$. — St. Ill 1, 550 - $546 \mathrm{~m}: 2 \widehat{\gamma} 15.5$ and $15.6 \mathrm{~mm}$.

MUSORSTOM II, Philippines, St. $25,13^{\circ} 39.0^{\prime} \mathrm{N}-120^{\circ} 42.6^{\prime} \mathrm{E}$, 550 - $520 \mathrm{~m}: 1$ ㅇ $20.5 \mathrm{~mm}$.

This species was described from a single female collected in the Andaman Sea at a depth of $823 \mathrm{~m}$. It does not seem to have been reported since and the male was previously unknown. For these reasons we have figured our material.

In our specimens the rostrum is more or less raised upward. The length of the antennular flagella is equal or slightly longer than that of the carapace; the inferior flagellum is composed of 55 to 62 segments. The second abdominal segment bears an indistinct carina. 


\section{PENAEOID SHRIMPS}

There is great similarity between the petasma of this species and that of faxoni De Man, 1907. However these two species clearly differ in the rostral shape, length of the antennular flagella, presence of an orbital spine in anmectens (absent in faxoni), a very sharp carina on third abdomnial segment in annectens (lacking in faxoni).

\section{Solenocera alfonso Perez-Farfante, 1981}

Solenocera alfonso Perez-Farfante, 1981, p. 631, fig. 1-5.

Material: CORINDON II - St. 273, $120-200 \mathrm{~m}$ : 1 o $17.4 \mathrm{~mm}$; 1 ㅇ $12.3 \mathrm{~mm}$.

This species was reported only from off the Philippines, at depths between 176 and $546 \mathrm{~m}$. It can be distinguished from all the other species of the genus by the spine on the postrostral carina, behind the cervical sulcus (similar in this respect to Haliporus steindachneri Balss, 1914).

\section{Family SICYONIIDAE}

Genus Sicyonia H. Milne Edwards, 1830

Sicyonia lancifer (Olivier, 1811)

Sicyonia lancifer, Bate 1888, p. 297, pl. 43, fig. 4. - De Man, 1911, p. 123. - Hall, 1962, p. 37, fig. 124, 124a - b.

Material: CORINDON II - St. 201, 21m: 1 \$ $10.2 \mathrm{~mm}$. - St. 205, 49 m: 1 ㅇ $10.3 \mathrm{~mm}$. - St. 292, $46 \mathrm{~m}, 1911.9 \mathrm{~mm}$. - St. 295, 54 - $51 \mathrm{~m}: 1$ ऊ $10.8 \mathrm{~mm} ; 1$ 우 $10.8 \mathrm{~mm}$.

Number and size of spines on abdominal pleura rather variable. Usually their distribution from the first to the fifth abdominal segment is $1,1,3,3$ and 3 , but two of our specimens have two spines on the pleuron of the second abdominal segment (making them close to cristata de Haan), and another one has only two spines on the pleuron of the fifth abdominal segment. It should be noted that on BATE's figure (1888, pl. 43, fig. 4) the third abdominal pleuron has only two spines which, according to DE MAN (1911), is also true for the specimen examined by him. This species was previously reported from Indonesia; it has a very wide distribution in the Indo-West Pacific, occurring at shallow depths. 


\section{AlAIN CROSNIER}

Sicyonnia inflexa (Kubo, 1949)

Sicyonia inflexa Kubo, 1949, p. 458, fig. 80, 48D, 77C and I, 79G, 159, 160A-F.

Material: CORINDON II - St. 217, 470-447 m: 1 ๙ $8.0 \mathrm{~mm}$. - St. 229, 445-411 m: 2 ㅇ 10.3 and $12.4 \mathrm{~mm}$.

Our specimens agree with Kubo's description. However, it is necessary to distinguish between Kubo's species S. longicauda RARHBUN (1906, p. 908, pl. 20, fig. 6) and S. fallax DE MAN (1911, p. 115; 1913, pi. 9, fig. $38,38 \mathrm{a}-\mathrm{c})$.

S. fallax was described from a single female collected in Indonesia, and $S$. longicauda from many specimens from off Hawaii. S. inflexa, described from 8 females does not seem to have been reported elsewhere except off Japan.

All these species occur in rather deep waters (inflexa at about 300 - $450 \mathrm{~m}$; longicauda at 450 to $550 \mathrm{~m}$; fallax at $275 \mathrm{~m}$ ).

\section{REFERENCES}

Alcock, A. 1901. A descriptive Cataloque of the Indian Deep-sea Crustacea Decapoda Macrura and Anomala, in the Indian Museum. Being a revised Account of the Deep-sea Species collected by the Royal Indian Marine Survey Ship "Investigator". Calcutta: I-IV 1-286, pi. 1-3.

Alcock, A. and A.F. MCARdLE 1901. Crustacea. Part IX. Illustrations of the Zoology of the Royal Indian Marine Surveying Steamer "Investigator", pi. 49. 55.

BALss, H. 1925. Macrura der Deutschen Tiefsee-Eacpedition. 2. Natantia, Teill A. Wiss. Erffebn. dt. THefsee-Exped. "Valdivia", 210: 217-315, fig. 1-75, pi. 20-28.

BATE, C.S. 1888. Report on the Crustacea Macrura Collected by H.M.S. "Challenger" during the Years 1873-76. In: Report scient. Res. Voyage H.M.S. "Challenger", Zoology, 17: I -XC, (1-942, fig. 1-76, pi. 1-150.

Crosnier, A. 1978. Crustaces D6capodes Peneides Aristeidae (Benthesicyminae, Aristeinae, Solenocerinae). Faune Madagascar, 46: 1 - 1S7, fig. 1-63.

CROSNIER A. and J. FOREST 1073. Les crevettes profondes de TAtlantique oriental tropical. Faune Tropicale, ORSTOM, 19: 1-400, fig. 1-121.

FREITAS, A.J. de 1979. A new genus and species of the penaeoid family Solenoceridae (Crustacea, Decapoda) from south-east African waters. Ann. S. Afr. Mus., 77 (7): 1123!-1131, fig. 1. 


\section{PENAEOID SHRIMPS}

Hall, D.N.F. 1961. The Malayan Penaeidae (Crustacea Decapoda) Part II. Further taxonomic notes on the Malayan species. Bull. Raffles Mus., 26: 76-119, pi. 17-21.

HALL, D.N.F. 1962. Observations on the taxonomy and biology of some Indo-WestPacific Penaeidae (Crustacea, Decapoda). Col Office Fish Publ, 17: 1-229, fig. 1-125, pi. 1, 4 pl. h.t.

KIM, ELS. 1977. Macrura. In: Illustrated Flora and Fauna of Korea, 19: 1-414, fig 1 - 162.

Kubo, I. 1949. Studies on the Penaeids of Japanese and its adjacent waters. J. Toxyo Coll Fish., 36 (1): 1-467, fig. 1-160.

LEE, D.A. and H.P. Yu 1977. The Penaeid shrimps of Taiwan. JCRR Fish. Ser., 27: 1-110, fig. 1-74.

MAN, J.G. de 1907. Diagnoses of new species of macrurous Decapod Crustacea from the "Siboga Expedition". II. Notes Leyden Mus., 29: 127-147.

MAN J.G. de 1011. Family Penaeidae. The Decapoda of the Siboga Expedition. Part I. Siboga Exped., monogr. 39a, 1 - 31.

MAN, J.G. de 1913. Family Penaeidae. The Decapoda of the Siboga Expedition. Part I. Siboga Exped., Suppl. Monogr. 39a, pi. 1-10.

PEREZ FARFAnTE, I. $1977^{1}$. American Solenocerid shrimps of the genera Hymenopenaeus, Haliporoides, Pleoticus, Hadropenaeus new genus and Mesopenaeus new genus. Fishery Bidl. Fish Wildl. Serv. U.S., 75 (2): 261-346, fig. 1-68.

PEREZ FARFANTE, I. U9®1. Solenocera alfonso, a new species of shrimps (Penaeoidea: Solenoceridae) from the Philippines. Proc. biol. Soc. Wash., 94 (2): 631 - 639, fig. $1-5$.

Perez FARfante, I. and D.I. Grey 1980. A new species of Solenocera (Crustacea: Decapoda: Solenoceridae) from Northern Australia. Proc. biol. Soc. Wash., 93 (2): 421-434, fig 1-7.

Starobogatov, Y.I. 1972. Penaeidae (Crustacea Decapoda) du golfe du Tonkin. In: Faouna tonkinaskava zaliva i ouslovia io southchestvovania. Akad. Nauk. SSSR. Zool. Institout. Isledovania Faoune Morel, X (XVIII) Isdatelstvo "Naouka" Leningrad: $359-415$ pi. 1-11. (in Russian).

Wood-Mason, J. and A. Alcock 1891. Natural History Notes from H.M. Indian Marine Survey Steamer "Investigator", Commander R.F. Hoskyn, R.N. Commanding. Series II. $N^{\circ} 1$. On the Results of Deep-sea Dredging during the Season 1890-91. Ann. Mag. Nat. Hist., (6) 8: 268-286, 353-362. 